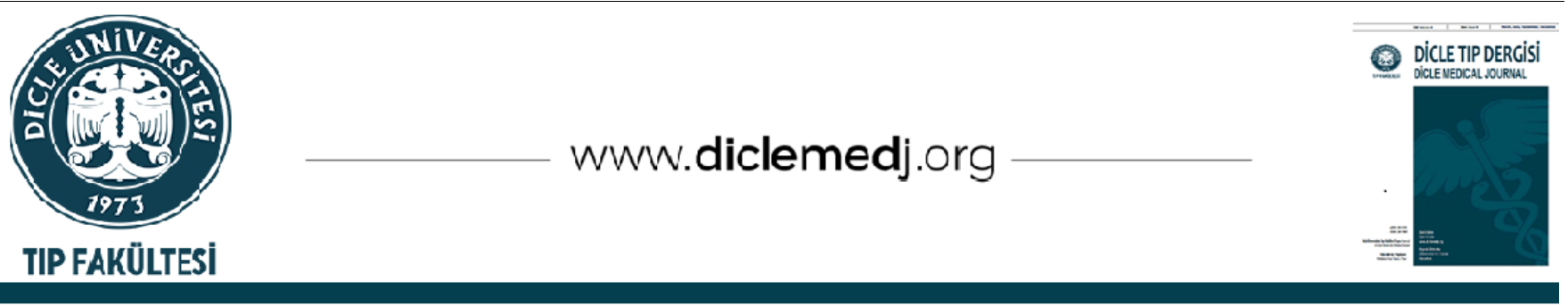

Original Article / Özgün Araştırma

\title{
The Differences Between Cases With Primary and Recurrent Shoulder Dislocation: A Tertiary Center Study
}

\author{
Ahmet Yesil iD 1, Mustafa Icer ${ }^{D}{ }^{2}$, Cahfer Güloglu ${ }^{\text {iD }}{ }^{2}$, Mehmet Gem ${ }^{3}$ \\ 1 Department of Emergency, Batman Training and Research Hospital, Batman, Turkey \\ 2 Department of Emergency, Dicle Univercity Medical Faculty,Diyarbakır, Turkey \\ 3 Department Of Orthopedy, Özel Memorial Hospital, Diyarbakır, Turkey \\ Received: 15.02.2021; Revised: 13.10.2021; Accepted: 26.10.2021
}

\begin{abstract}
Objective: The aim of this study is to compare demographic and clinical characteristics of cases with primary and recurrent shoulder dislocations.

Methods: Cases who presented to a tertiary center Emergency Medicine Clinic with shoulder dislocation between January 2013 and December 2016 were evaluated.The cases were divided into two groups as primary (Group 1) and recurrent (Group 2) dislocations.Characteristics such as age, gender, seasonal period, dislocation side, causes of trauma, accompanying additional injuries and treatment modalities were compared between the groups.

Results: 119 cases were included in the study. 64.7\% ( $\mathrm{n}=77)$ of the cases were classified as Group 1, and 35.3\% (n=42) as Group 2. There was no difference between Group 1 and Group 2 in terms of age, gender and dislocation side (P values: 0.484, 0.570, 0.251, respectively). Inferior dislocations were more common in Group $1(n=7 / 77)$ compared to Group 2 ( $n=1 / 42$ ), and a statistically significant difference was found $(\mathrm{p}=0.009)$. Group 2 cases $(\mathrm{n}=19 / 42)$ were found to be more common in the spring than group 1 $(n=17 / 77)(p=0.012)$. Additional injuries were detected in $8.4 \%$ of the cases $(n=10 / 119), 8$ of them were in group 1 and 2 of them were in group 2, and there was no statistically significant difference between the groups in terms of additional injury ( $\mathrm{p}=0.491$ ). $11.8 \%$ $(n=14)$ of the cases were hospitalized by orthopedics for surgery (open reduction) or closed reduction under general anesthesia. Surgical treatment (open reduction) was applied in 23.8\% ( $\mathrm{n=10/42)}$ in Group 2, and 5.2\% ( $\mathrm{n}=4 / 77)$ in Group 1, and a statistically significant difference was found between the groups $(\mathrm{p}=0.005)$.
\end{abstract}

Conclusion: It was found that surgical treatment was preferred more frequently on recurrent dislocations compared to primary dislocations. Therefore, we recommend that cases with a history of primary dislocation should take precautions for trauma during active periods of social life.

Key words: Shoulder dislocation; primary; recurrent; demographic

DOI: 10.5798/dicletip.1037596

Correspondence / Yazışma Adresi: Ahmet Yeşil, Department of Emergency, Batman Training and Research Hospital, Batman, Turkey, e-mail: ahmet.yesil2100@gmail.com 


\section{Primer ve Rekürren Omuz Çıkıklı Olguların Karşılaştırılması: Bir Tersiyer Merkez Çalışması}

\section{Öz}

Amaç: Bu çalışmanın amacı, primer ve rekürren omuz çıkıklı olguların demografik ve klinik özelliklerini karşılaştırmaktır.

Yöntemler: Ocak 2013-Aralık 2016 tarihleri arasında omuz çıkı̆̆ı şikayeti ile üçüncü basamak Acil Tıp Kliniği'ne başvuran olgu

lar değerlendirildi. Olgular primer (Grup 1) ve rekürren (Grup 2) çıkık olmak üzere iki gruba ayrıldı. Yaş, cinisiyet, mevsimsel dönem, çlkık tarafı, travma nedenleri, eşlik eden ek yaralanmalar e tedavi yöntemleri gruplar arasında karşıllaştırıldı.

Bulgular: Çalışmaya 119 olgu dahil edildi. Olguların \%64,7’si (n=77) Grup 1, \%35,3’ ü (n=42) Grup 2 olarak değerlendirildi. Grup 1 ve Grup 2 arasında yaş, cinsiyet ve çıkık tarafı açısından fark bulunmadı (Sırasıyla p değerleri: 0.484,0.570,0.251). Grup 1' de (n=7/77), Grup 2' ye (n=1/42) kıyasla inferior çıkıklar daha yaygındı ve istatistiksel olarak anlamlı fark saptandı (p=0,009). Grup 2 olguların (n=19/42) ilkbahar mevsiminde, grup 1' e (n=17/77) göre daha yaygın olarak görüldüğü saptandı (p=0.012). Olguların \%8,4' ünde ( $n=10 / 119)$ ek yaralanma saptandı bunların 8' i grup 1 olup 2 olgu grup 2 de yer almaktaydı ve ek yaralanma açısından gruplar arasında istatistiksel olarak anlamlı olarak bir fark bulunamadı $(\mathrm{p}=0.491)$. Olguların \%11,8'i $(\mathrm{n}=14)$ ameliyat (açık redüksiyon) veya genel anestezi altında kapalı redüksiyon için ortopedi tarafından yatırıldı. Grup 2' de \%23,8' inde (n=10/42) cerrahi tedavi (açık redüksiyon) uygulanmış olup, Grup 1' de ise \%5,2' sinde (n=4/77) uygulandı ve gruplar arası istatistiksel olarak anlamlı fark saptandı $(\mathrm{p}=0.005)$.

Sonuç: Sonuç olarak bu çalışmada rekürren çıkıklarda cerrahi tedavinin daha çok uygulandığı tespit edildi. Bu nedenle daha önce primer çıkı öyküsü olan olguların bir sonraki çlkık gerçekleşmesi durumunda cerrahi müdahalelerin artacağından dolayı sosyal hayatın aktifleștiği dönemlerde travmaya yönelik önlemler almasını önermekteyiz.

Anahtar kelimeler: Omuz çıkığı; primer; rekürren; demografik.

\section{INTRODUCTION}

Shoulder dislocation is the most frequently seen joint dislocation in the body and is the most important cause of shoulder instability ${ }^{1}$. In addition, it is the most mobile and the largest joint in the body. Therefore it is susceptible to trauma because it is one of the most active joints in the body. It takes part in the body's selfprotection reflex, leading to frequent injuries ${ }^{2}$. Shoulder dislocations constitute approximately $45 \%$ of all joint dislocations and $85 \%$ of these are anterior dislocations ${ }^{3}$.

Traumatic, atraumatic, micro traumatic, neuromuscular and congenital causes play a role in the etiology of shoulder dislocation. $96 \%$ of shoulder dislocations are traumatic (as a result of major trauma) and $4 \%$ are atraumatic (spontaneous) ${ }^{4}$. Shoulder instability is divided into two groups as acute and chronic according to the frequency of occurrence. The acute phase can be defined as an instability that manifests itself hours or days after the first (primary) dislocation. Dislocations other than this are defined as chronic. If the dislocation has occurred many times and is unstable, it is called recurrent shoulder dislocation ${ }^{5,6}$.

Careful anamnesis and physical examination are very important in the evaluation of cases suspected for glenohumeral instability. The diagnosis of a patient who has applied to the emergency room with acute glenohumeral dislocation can be made with radiographs. Conservative treatment is primarily for dynamic factors. Most cases who have had acute traumatic shoulder dislocation for the first time are treated conservatively. The shoulders are conventionally immobilized for a certain period of time in internal rotation with an arm sling or Velpeau bandage ${ }^{7}$. In recurrent dislocations, surgical treatment is recommended to ensure range of motion and prevent subsequent instabilities ${ }^{8}$.

The aim of this study is to compare demographic and clinical characteristics of cases with primary and recurrent shoulder dislocations. 


\section{METHODS}

In this study, cases who presented to a tertiary center Emergency Medicine Clinic with shoulder dislocation between January 2013 and December 2016 were evaluated. Before the study, approval was obtained from the ethics committee of our university (Ethics committee number: 2018/222).

All cases with traumatic or spontaneous shoulder dislocation alone or accompanied by fracture and/or additional injuries, scanned with the ICD-10 code S40-S49 in the hospital data processing system, were included in the study. The diagnosis of shoulder dislocation was made in combination with clinical examination and imaging. Cases with incorrect ICD-10 code with no shoulder dislocation were excluded from the study. The data was obtained from the files in the hospital archive.

The cases were divided into two groups as primary (Group 1) and recurrent (Group 2) dislocations. Primary dislocation was defined as the first shoulder dislocation in a patient who did not have a shoulder dislocation before, and recurrent dislocation was defined as the dislocation of the same shoulder at least once before. Characteristics such as age, gender, seasonal period, dislocation side, causes of trauma, accompanying additional injuries and treatment modalities were compared between the groups. The dislocation side was evaluated as the right and left shoulder. Treatment modalities were divided into two groups as manual reduction and surgery.

\section{Statistical Analysis}

Data were presented as mean \pm standard deviation and number (percentage). Chi-square test was used for categorical variables and Student-t test was used for continuous variables. While evaluating the differences between subgroups, Chi-square test was used for the data obtained by counting, and MannWhitney $U$ test was used for the data obtained by measurement. OneWay ANOVA (One Way Analysis of Variance) and Kruskal Wallis test were used in multiple groups. SPSS 15.0 program was used for statistical analysis and $\mathrm{P}$ value $<0.05$ was considered significant.

\section{RESULTS}

154 cases files were evaluated during the study period. 35 cases with an incorrect ICD 10 code and no shoulder dislocation were excluded from the study. 119 cases were included in the study. $64.7 \%(n=77)$ of the cases were classified as Group 1, and 35.3\% ( $n=42)$ as Group 2. There was no difference between Group 1 and Group 2 in terms of age, gender and dislocation side (P values: $0.484,0.570,0.251$, respectively). Inferior dislocations were more common in Group $1(\mathrm{n}=7 / 77)$ compared to Group 2 $(\mathrm{n}=1 / 42)$, and a statistically significant difference was found ( $\mathrm{p}=0.009)$. Group 2 cases $(n=19 / 42)$ were found to be more common in the spring than group $1(n=17 / 77)(p=0.012)$. Spontaneous dislocations were detected in 7 of 77 cases in group 1 and in 24 of 42 cases in group 2. Additional injuries were detected in $8.4 \%$ of the cases $(n=10 / 119), 8$ of them were in group 1 and 2 of them were in group 2, and there was no statistically significant difference between the groups in terms of additional injury $(p=0.491) .11 .8 \%(n=14)$ of the cases were hospitalized by orthopedics for surgery (open reduction) or closed reduction under general anesthesia. Surgical treatment (open reduction) was applied in $23.8 \%(n=10 / 42)$ in Group 2, and 5.2\% ( $\mathrm{n}=4 / 77)$ in Group 1, and a statistically significant difference was found between the groups ( $p=0.005)$.

Demographic data and clinical characteristics were compared between the groups (Table I). 
Table I: The demographic and clinical differences between the groups.

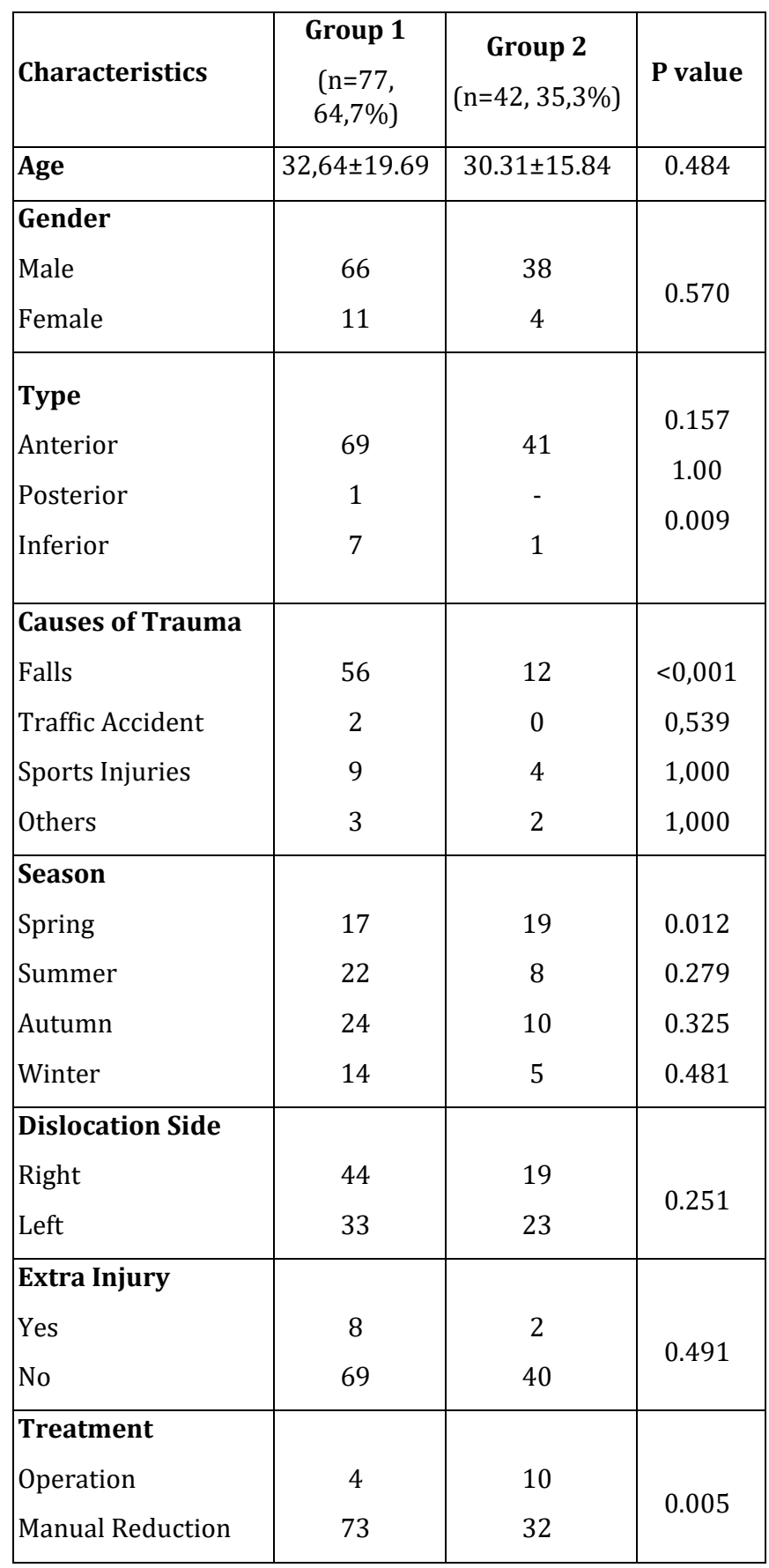

\section{DISCUSSION}

Demographic and clinical characteristics of cases with primary and recurrent shoulder dislocations were compared in this study. It was determined that dislocations occurring in the inferior location were more common in primary dislocations, recurrent dislocations were more common in the spring, and surgical treatment was mostly applied in recurrent dislocations.

A complex joint, shoulder joint consists of the glenohumeral joint, acromioclavicular joint, sternoclavicular joint, and scapulothoracic joint ${ }^{9}$. Glenohumeral dislocation is the most common joint dislocation in the body and is the most important cause of shoulder instability ${ }^{1}$. At the same time, it is the most mobile and the largest joint in the body, therefore it is susceptible to trauma because it is one of the most active joints in the body ${ }^{2}$.

In many studies, one of the most important factors in determining the risk of recurrent dislocation is the age at which primary shoulder dislocation occurs ${ }^{1,4,10}$. In a study where Rowe et $\mathrm{al}^{4}$ followed 488 cases for 20 years, they found a recurrence rate of $83 \%$ in cases under 20 years of age and $16 \%$ above the age of 40 . Similarly, Te Slaa et al. ${ }^{10}$ found this rate as $64.40 \%$ under 20 years of age and $4 \%$ over the age of 20 . When the literature was evaluated, we could not find a study comparing primary and recurrent dislocations in terms of age, gender and dislocation side. 42 (35.3\%) of the cases in this study had recurrent dislocations, and no difference was found between primary and recurrent dislocations in terms of age, gender and dislocation side.

In a study comparing 33 primary and 111 recurrent dislocations, anteroinferior dislocations in the primary and recurrent groups were reported as 22 (66.6\%) and 109 (98.1\%), respectively. The incidence of anteroinferior dislocation was higher in recurrent cases than in primary cases ${ }^{11}$. When the literature was evaluated, no other study evaluating the location of primary and recurrent dislocations could be found. In the present study, cases were evaluated as anterior, inferior and posterior dislocations, and it was found that inferior dislocations were more common in primary dislocations, contrary to 
the literature. We believe that this may be associated with the way the trauma occurs.

In the literature on shoulder dislocations, no study evaluating the relationship between shoulder dislocation cases and seasonal distribution was found. In this study, it was found that recurrent dislocations were more common in the spring than primary dislocations. We believe that this may be associated with temperature distribution. In addition, the fact that people spend more time outdoors and engage in more activities due to the increase in air temperature, and higher trauma exposure can also be a factor.

In studies evaluating additional injuries in the literature, Rowe et al. ${ }^{4}$ reported additional pathology in $15 \%$ of the cases. Taș et al. ${ }^{12}$ found additional pathology in $11.5 \%$ of the cases. In this study, additional pathology was found in 10 cases, and no statistically significant difference was found between the groups according to the literature.

In studies evaluating the causes of traumatic shoulder dislocation, it was found that an average of $75 \%$ of the shoulder dislocations were due to falls and almost all shoulder dislocations in women were due to falls. In men, sports injuries and traffic accidents have been identified as other important causes in addition to falls ${ }^{1,12,13}$. In this study, falls were the most common cause of trauma in both groups. Although the primary reason for recurrent dislocations is spontaneous dislocations, the most common traumatic cause with primary dislocations is falls.

In a study in which 33 cases with primary traumatic anterior shoulder dislocation were examined, closed reduction was applied to 17 of the cases and open reduction was applied to 16 cases $^{1}{ }^{4}$. While Kroner et al. $^{15}$ applied closed reduction to $85.5 \%$ of the cases and followed them as outpatients, $18.6 \%$ of the cases were hospitalized after closed reduction under surgery or general anesthesia. Apart from these, there are many treatment methods and techniques defined in cases with shoulder dislocation ${ }^{16}$. In this study, 105 of the cases were followed up as outpatients after closed reduction in consistent with the literature. The remaining 14 cases were hospitalized by orthopedics for surgery (open reduction) or closed reduction under general anesthesia. Ten of fourteen cases that underwent open reduction were in the recurrent dislocation group. Surgical treatment was more common in recurrent dislocations than primary dislocations.

\section{CONCLUSION}

It was found that the inferior location was more common in primary dislocations compared to recurrent dislocations, while recurrent dislocations were seasonally more frequent in the spring, and surgical treatment was preferred more frequently on recurrent dislocations compared to primary dislocations. Therefore, we recommend that cases with a history of primary dislocation should take precautions for trauma during active periods of social life.While the likelihood of surgical interventions will increase, another dislocation occurs.

Acknowledgments: We would like to thank Mehmet Üstündağ for his assistance with the statistics used in this report. The authors declare that this study has received no financial support.

Ethics Committee Approval: Before the study, approval was obtained from the ethics committee of our university (Ethics committee number: 2018/222).

Declaration of Conflicting Interests: The authors declare that they have no conflict of interest.

Financial Disclosure: No financial support was received. 


\section{REFERENCES}

1. Owens BD, Duffey ML, Nelson BJ, et al. The incidence and characteristics of shoulder instability at the United States Military Academy. Am J Sports Med. 2007; 35:1168-73.

2. Lippit S, Matsen F.A. Mechanisms of glenohumeral joint instability. Clin Orthop. 1993; 291: 20-8.

3. Kazar B, Relovszky E. Prognosis of primary dislocation of the shoulder. Acta Orthop Scand. 1969; 40: 216-24.

4. Rowe C.R. Prognosis in dislocations of the shoulder. J Bone Joint Surg Am. 1956; 38: 957-77.

5. Yalaman 0. Reduksiyonu gecikmiş travmatik omuz çıkıklarında tedavi sonuçları. İstanbul Tıp Fakültesi. Tez - 1979.

6. Hawkins R.J, Neer C.S, Pianta RM, et al. Locked posterior dislocation of the shoulder. J Bone Joint Surg Am. 1987; 69: 9-18.

7. Itoi E, Hatakeyama Y, Kido T, et al. A new method of immobilization after traumatic anterior dislocation of the shoulder: a preliminary study. J Shoulder Elbow Surg. 2003; 12: 413-5.

8. Arciero RA, Wheeler JH, Ryan JB, et al. Arthroscopic Bankart repair versus nonoperative treatment for acute, initial anterior shoulder dislocations. Am J Sports Med. 1994; 22: 589-94.

9. Hawkins RJ, Abrams JS. Impingement Syndrome in the Absence of Rotator Cuff Tear (Stage 1 and 2). Orthop. Clin.North.Am. 1987; 18: 373-82.
10. Te Slaa RL, Wijffels MP, Brand R, et al. The prognosis following acute primary glenohumeral dislocation. J Bone Joint Surg Br. 2004; 86: 58-64.

11. Kim DS, Yoon YS, Yi CH. Prevalence Comparison of Accompanying Lesions Between Primary and Recurrent Anterior Dislocation in the Shoulder. Am J Sports Med. 2010; 38(10): 2071-6.

12. Taş M, Canbora K, Köse O, et al. Türkiye'nin bir şehrindeki travmatik omuz çıkıklarının demografik ve klinik özellikleri:208 olgunun geriye dönük analizi. Acta Orthop Traumatol Turc. 2013; 47: 14752 .

13. Zacchilli MA, Owens BD. Epidemiology of shoulder dislocations presenting to emergency departments in the United States. J Bone Joint Surg Am. 2010; 92: 542-9.

14. Handoll H.H.G, Al-Maiyah M.A. Surgical versus non-surgical treatment for acute anterior shoulder dislocation. Cochrane Database of Systematic Review. Version published: 26 January 2004.

15. Krøner K, Lind T, Jensen J. The epidemiology of shoulder dislocations. Arch Orthop Trauma Surg. 1989; 108: 288-90.

16. Özden R, Uruç V, Duman İ, et al. Akut akromioklaviküler eklem çıkıklarında endobutton ile tesbit yöntemi. Dicle Tıp Dergisi. 2014; 41: 26871. 